IJ§ER

ISSN: 2149-5939
International Journal of Social Sciences and Education Research

Online, http://dergipark.gov.tr/ijsser

Volume: 3(1), 2017

\title{
Impact of domestic violence in the manifestation of aggressive be- havior among adolescent aged 15
}

\author{
Armen Mustafa ${ }^{1}$
}

\begin{abstract}
Received Date: 08/ o9 / 2016
Accepted Date: 17 / 12 / 2016

Abstract

The main purpose of this study is to explore the impact of domestic violence in the manifestation of aggressive behavior among adolescents. Through this research study is aimed to promote research in this area for the purpose of awareness of people and society in Kosovo for consequences of domestic violence in general and children in particular. The reason for such a study lies in the fact that Kosovo society as a society in transition still suffering from the consequences of war and extreme Serbian violence, increasingly spreading phenomena which are based violence, such as domestic violence, violence against children, violence in schools, youth delinquency, etc. For this is designed a case study to get a unique perspective on the experience of domestic violence and its impact on the behavior of a teenager aged 15. Case study was conducted mainly through semi-structured interview. The data were supplemented with additional interviews with other persons and analyzed documentation. Data analysis was done through analysis of the phenomenological interpretation. The main question which is based on the study has been: Why adolescents aged 15 years from families with a history of violence demonstrate aggressive behavior toward others? The case study shows that adolescents in this age because of violence experienced, along with other problems, also demonstrate aggressive behavior, often by modelling the parents' behavior.
\end{abstract}

Keywords: Domestic violence, violence against children, the aggression, adolescence

\section{Introduction}

The end of the war and structured Serbian violence and transition in Kosovo, were accompanied by numerous problems, which as a base had violence, such as domestic violence, violence against children, violence in school, youth delinquency and criminality, etc. (Office for Protection and Victim Assistance, 2014; Kosovo Police, 2013; Kosovo Probation Service, 2010).

The impact of domestic violence on children has attracted the attention of many researchers. Thus, Mcgee (2000), in a study conducted in England and Wales, having interviewed 48 mothers and 54 children (ages 5- 15) who have experienced domestic violence concludes that the experience of domestic violence affecting children in: appearance of fear, depression, family relationships deteriorated, low academic achievement, aggressive behavior. Many researchers emphasize the role that aggressiveness learning has through imitation of models (Baker, Jafet, Ashbourne and Carter, 2002; Kaufman, 1997). This increases the risk that these children become abusive in the future. It has been proven by Sheehan (1997. In Laing, 2000), in which a sample of 60 families of aggressive adolescents found that only 11 of them had no history of domestic violence experience.

\footnotetext{
${ }^{1}$ PhD Candidate, Probation Service, Pristina /KOSOVO, armenmustafa@gmail.com
} 
Mustafa, A. (2017). Impact of domestic violence in the manifestation of aggressive behavior among adolescent aged 15. International Journal of Social Sciences and Education Research, 3(1), 106-110.

\section{Purpose of the study}

The purpose of the study is to explore the impact that domestic violence has in the manifestation of aggressive behavior among adolescents. The main question on which the study is based and which is aimed to be answered by this study is: Why adolescents aged 15 years from families with a history of violence demonstrate aggressive behavior toward others?

\section{Methodology}

The data in this study come from $\mathrm{PhD}$ study about violence against children in society and its impact on children's behavior. The study is based on qualitative methodology of the case study. Selection to be done a case study has to do with the fact that the study method allows for a deeper study of this phenomenon in a given case. Case selected is typical representative for other cases, within the phenomenon being studied case selection (Petrit - imaginary name) as a case study was made based on experience and behaviors that he manifested recently. $\mathrm{He}$ is 15 years old and has completed ninth grade. He has being prosecuted on court proceedings for injury to another person. His parents are divorced but living under the same roof. The study was designed so that the perspective and experience of Petrit is central, which will be based on the data collection and analysis. Initially the study was taken an oral and written informed consent by Petrit's mother. Except her, even Petrit was informed and agreed to this. Data collection is done through the process of semi-structured interview. There is built an instrument for interview, with the topics that will be addressed during the interview: History of violence in the family; types of violence that were used in the family and frequency; how is to live in the family with history of violence; manifestation of aggressive behavior by adolescent, time, types and attitudes; and other problems resulting from adolescent behavior.

The questions were opened, to encourage Petrit give detailed descriptions of his experiences and phenomenological experience. Also, are made the semi-structured interviews with other persons, respectively mother and a teacher. Moreover, has been reviewed and analyzed various documents which have to do with Petrit and his family. These include documents such as:

- Class daybook of VIII and XI grade of the school where Petrit attended lessons;

- School principal's daybook for troublemaker students,

- Social Inquire Report of Probation Service addressed Prosecution, AS- number 247,

- The decision of the Basic Court in Pristina, released an Order of an Emergency Protection of the Petrit's family from his father, with the number C.nr.1866.

After the interview, their transcription is made, and based on the principles of the phenomenological interpretation is also done their analysis (Willig, 2008, p.58). Analysis procedure was performed in four steps: a) The first step involves their reading and rereading until they realize in detail; b) secondly are identified those statements dealing with the problem being studied; c) thirdly to identify the most important topics, these statements were grouped; and d) fourthly became generalizations of topics in more general categories. On the basis of these has been made analyzes of documents.

The study has its limitations. One of these is the premeditated choice of the case, which affects the data generalization. Then, when considering the study problem, is concluded that 
Mustafa, A. (2017). Impact of domestic violence in the manifestation of aggressive behavior among adolescent aged 15. International Journal of Social Sciences and Education Research, 3(1), 106-110.

just methods used in the case is not enough. In the contest, teenager observation in certain environments (ex. school), would give much clearer data of the case.

\section{Results}

As a result of the interviews' analysis were identified three main themes (categories): "Experiencing of violence", "psychological state" and "Petrit behavior and attitudes."

\subsection{The experiences of violence}

Within this category are included declarations of domestic violence experiences by Petrit, time when did it start, violence forms which are used in his family, its duration, frequency and causes. In this regard Petrit says:

I grew up with violence. Since I remember, father beat mother and beat us, but mother was beaten severely. Since when we returned from Germany it has happened more frequently, almost no day that there had not argued of such things.

Petrit's mother speaks almost the same thing:

Since marriage he began with different jealousy words. Later began beatings. These are not ever stopped, but have intensified especially since we returned from Germany. Children have seen and experienced everything until today.

Petrit shows many events that has experienced. Here's one of them, during confession which turned him to tears:

Once, when we were watching television after dinner, my father began to ask mother where she was today, who was at home the kind of question and immediately ordered us to go to our room to sleep. We knew what will happen and he began to scream, we heard the crash of things and the voice of the mother. In the morning my mother had some bruises on her face.

Violence by the father in the Petrit's family evidenced in the Basic Court decision, where the reasoning of the decision rendered by this court stated that:

The Court concludes, based on evidence that physical and psychological violence used against protected parties represents abuse, neglect and violation of human rights.

\subsection{Psychological state}

Experiencing domestic violence, however, has had a significant impact on the Petrit's psychological state. Being witness of the violence often experienced in his skin, Petrit speaks how he felt in such situations:

When I was little boy, I was afraid in such cases. I felt terrified to speak or cry, it was because I knew that I would incur too.

Nevertheless he made a separation between the past, namely "when he was a boy" and now. Now feels strong enough and has no fear of his father, he stares up and says:

Now I have no fears of father. I can't stand him. I just cannot see what he is doing to mother, or others. I have watched him enough. 
Mustafa, A. (2017). Impact of domestic violence in the manifestation of aggressive behavior among adolescent aged 15. International Journal of Social Sciences and Education Research, 3(1), 106-110.

\subsection{Behaviors and attitudes}

By overcoming the fear, Petrit gradually begins to behave differently. This difference mother has observed initially when Petrit argues with his father, and then protecting her in certain cases by the husband's attacks.

There is a long time that he argues with his father. In some cases when he has been there Petrit protected me from husband, even fighting with him.

However, this change in Petrit's behavior started to bother mother, because he has started to behave differently even to others. So, she says:

When I speak something that he dislikes, he reacts and begins to shout. Also, when the younger brother begins to play and when we do not indulge him something becomes irritable and aggressive, on the other side in school, has had problems with students and teachers. I fear he will become like his father.

At school these changes in Petrit's behavior were observed better. Here's what the teacher says about this:

$\mathrm{He}$ is aggressive with friends and teachers, but the worst is that he has missed a lot of classes, he comes whenever wants to. He was a very nice guy and seemed mature, but in last two years he has changed a lot. Not able to speak with.

This can be seen in school documentation. There Petrit is seen, that while he was in eighth grade began to miss the learning process, the success decreased, remark discipline in the classroom, and in the ninth-grade situation worsens. For this he takes disciplinary measure, preexpulsion from school.

Also, after a dispute he stabbed a school peer, causing minor injuries. The same happens in the family, where after an argument with cousin, attacks with a knife causing slight injury where is initiated court proceeding against him. For all these cases, Petrit was justified by blaming to others:

They harass me first. Tease, insult and swear on me, even more they are jealous on me and I cannot stand it.

\section{Discussion}

If we look at the results, we see the experienced domestic violence has affected Petrit's live and behavior. His own statement that: "I have grown up with violence" in some way means a lot. Shows that he is accustomed to living with violence and violence is nothing special.

According to the social learning theory of aggression, learning by observation includes four processes: attention process, storage process, production processes and motivation processes (Bandura, 1977. In Vasta. \& others, 1992, p.62). The first two processes occurred to Petrit through time, and the production process of aggression comes into consideration in adolescence age, when he considers himself quite mature to react and protect himself and others. So, Petrit having the only response model of conflict resolution and violence, proves that all conflicts and grievances chooses to resolve being aggressive. In this way aggressiveness has become acceptable to Petrit, as a communication form with others. He often arm touches and glances from others considers as motifs with hostile purposes, because aggressive children are 
Mustafa, A. (2017). Impact of domestic violence in the manifestation of aggressive behavior among adolescent aged 15. International Journal of Social Sciences and Education Research, 3(1), 106-110.

often unable to read social information on the environment (Vasta \& others, 1992, p. 493). Finally by Petrit case we can say that:

Aggressiveness is part of those children who grow up in the environment that reinforces aggressiveness, which provides aggressiveness models, moreover frustrates and victimize them, and teaches them that aggression is acceptable (Anderson \& Hussmann, 2003, p. 316).

Based on the findings of research, we have proposed a number of recommendations, which are mainly addressed at the institutional level and policy-making for protection against domestic violence.

- Establishment of multi professional teams in schools such with psychologists, social workers and other professionals must be a priority. These teams would be a great help to students, parents and others, to overcome the difficulties they have.

- Establishing and supporting services to help victims who experience domestic violence, especially for children.

- Development of various prevention programs and base interventions in community to reduce domestic violence, especially programs for positive parenting.

- Awareness campaign about the consequences of domestic violence and encouragement to report domestic violence.

\section{References}

Anderson, C. A., \& Huesmann, L. R. (2003). Human aggression: A social-cognitive view (pp. 296323). In M. A. Hogg \& J. Cooper (Eds.). The Handbook of Social Psychology, Revised Edition. London: Sage Publications. (2007).

Baker, L.L., Jaffe, P.G., Ashbourne, L \&. Carter, J., (2002). Children Exposed to Domestic Violence. Centre for Children and Families in the Justice System. Available: www.lfcc.on.ca

Office for Protection and Victim Assistance, (2014). 12 years serving the victims of crime.The State Prosecutor. Pristina

Kauffman, J.M., (1997). Characteristics of Emotional and Behavioral Disorders of Children and Youth. $\left(6^{\text {th }}\right.$ Ed.). Prentice-Hall

Laing, L., (2000). Children, young people and domestic violence. Australian Domestic \& Family Violence. Available: www.ausdvclearinghouseunsw.edu.au

McGee, C., (2000). Childhood Experiences of Domestic Violence. London and New York, Jesica Kingsley Publishers.

Kosovo Police, (2013). Statistical report. Analysis and Crime Directorate. Available: www.kosovopolice.com

Kosovo Probation Service, (2010). Bulletin No. 4. Pristina.

Vasta R., Haith M. M. \& Miller S. A., (1992). Child psychology. Modern science. Tirana, 2007,

Willig, C., (2008). Introducing in Qualitative Research in Psychology ( ${ }^{\text {nd }}$ Ed.). Open University Press. 